\title{
Does Lead Time in CEO Succession Matter? Evidence From Planned Versus Unexpected CEO Departures
}

\author{
Mia L. Rivolta ${ }^{1}$ \\ ${ }^{1}$ Finance Department, Xavier University, Cincinnati, Ohio, United States \\ Correspondence: Mia L. Rivolta, Ph.D., Finance Department, Xavier University, Cincinnati, Ohio, United States.
}

Received: April 16, 2018

Accepted: April 26, 2018

Online Published: May 6, 2018

doi:10.5430/ijfr.v9n3p1

URL: https://doi.org/10.5430/ijfr.v9n3p1

\begin{abstract}
This paper investigates whether and how lead time in CEO succession matters by comparing disruption costs in firms with planned retirements to those with unexpected CEO departures due to death or illness. Using a comprehensive manually-collected dataset of CEO turnovers from 1999 to 2008, I find evidence that firms with planned CEO retirements have significantly longer lead time and lower disruption costs. Specifically, longer lead time is associated with more favorable cumulative stock performance and firm operating performance around the outgoing CEO's departure. In fact, firms can save approximately $\$ 136$ million when there is lead time to plan for succession.
\end{abstract}

Keywords: CEO turnover, CEO succession, board of directors

JEL Classification: G30, G34, J33, M51

\section{Introduction}

CEO succession planning is the process by which the board of directors prepares for the transition of leadership from one CEO to the next. It is cited as one of the most important yet challenging roles of the board (Biggs, 2004). A lack of CEO succession planning is disruptive and increases business risk. Furthermore, this disruption in business activities creates costs that adversely affect shareholder wealth (Vancil 1987). The perceived importance of CEO succession planning is underscored by the Security and Exchange Commission (SEC) recommendation (SEC Staff Legal Bulletin 14E, 2009), which suggests firms to include a CEO succession planning proposal in their proxy statements. Despite the importance of CEO succession planning, literature on its necessity and process of the transition has been scarce, possibly because firms are hesitant to disclose detailed succession planning information (Note 1). Hence, it is likely that scarcity of empirical evidence on CEO succession planning is driven by the fact the planning process is difficult to observe and evaluate.

In this study, I overcome the lack of publicly-available details on succession planning by inferring the process and observing the lead time-the time between the outgoing CEO's departure announcement and the actual departure date to gauge the time firms have to plan for succession, if there is no plan already in place. Studying the lead time allows us to peek into the black box of CEO succession planning and observe actions firms take in the succession process. McConnell and Qi (2016) argue that there is a significant increase in firms claiming that they have a CEO succession plan in place since the SEC rule change. However, to the extent that this rule change can be cosmetic in nature, it is difficult to decipher whether firms genuinely have a succession plan in place or are just "window dressing".

I intend to evaluate the fundamental questions regarding CEO succession planning. First, I examine whether and how CEO succession matters by investigating whether lead time in CEO succession is important. Specifically, I examine whether firms with planned CEO departures (i.e., through retirements) have longer lead time and lower disruption costs compared to firms with unexpected CEO departures (i.e., due to death, illness, and sudden resignation). Presumably, firms with planned CEO retirements have two advantages over those with unexpected CEO departures. First, the incumbent CEO can still be involved in the selection and grooming of his/her successor. Second, firms will have time to make changes to their board in preparation for the succession, likely resulting in a smoother transition and lower disruption costs. On the contrary, firms with unexpected CEO departures not only lack incumbent CEOs' involvement in the selection process, but also are less likely to have time to prepare for CEO succession if there is no plan already in place, therefore may experience greater disruption costs. Second, I investigate which actions firms and board of directors may take to prepare for a smoother transition. Albeit not a perfect measure for the actual 
length or depth of the succession planning process, I argue that lead time is a reasonable proxy for the likelihood of succession planning in that it allows firms to compose a succession plan even if there is none in place.

To conduct this research, I hand-collect information for 919 CEO departures, including 843 planned and 76 unexpected CEO departures, during the period of 1999 to 2008 from the database Execucomp. I identify the very first public announcement of the CEO departure and collect detailed information about the departure from Factiva, Lexis-Nexis, and firms' SEC filings to categorize the cause of departure. A CEO departure is categorized as planned if the outgoing CEO's departure announcement contains key terms indicating that the departure is part of an orderly transition of power (Note 2). Unexpected CEO departures, by contrast, include departures due to sudden death, illness, or resignation. I used three measures to proxy disruption costs: (1) cumulative market-adjusted stock returns around the departure announcement; (2) Change in industry adjusted return on assets (ROA) and (3) change in industry-and-performance-adjusted ROA to control for possible operating performance mean reversion (Barber and Lyon 1996). Change industry-and-performance-adjusted ROAs are measured from one year before to three years after the incumbent CEOs' actual departure date.

I find that firms with planned CEO retirements have significantly longer lead time (75.70 days versus 3.53 days) as well as lower disruption costs compared to those with unexpected CEO departures. In particular, firms with planned CEO retirements have significantly less negative cumulative abnormal returns (on average $0.11 \%$ compared to $-2.18 \%$ ) three days around the departure announcement and higher excess stock returns for at least 30 days after the departure announcement. In fact, shareholder value is approximately $\$ 136$ million higher if the outgoing CEO retires compared to if he/she unexpectedly died or became ill. In addition, firms with planned CEO retirements are associated with better firm operating performance and higher firm values. These findings regarding the relationship between lead time and the disruption costs of the CEO succession are supported by several robustness tests, including propensity score matching and compare firms with above and below median lead time, to account for the potential sample selection bias between firms with planned retirement and those with unexpected departures.

The second empirical test examines the changes firms and directors make to the board in anticipation of the CEO departure. Simple univariate tests show that in order to prepare for succession, firms with planned departures are significantly more likely to implement two strategies. First, they are more likely to use relay successions with an heir apparent - typically the COO and/or president who are at least five years younger than the incumbent CEO (Canalla and Shen 2001, Shen and Canalla Jr. 2003, Zhang and Rajagopalan 2004, Behn, Riley Jr. and Yang 2005). Specifically, the heir apparent is appointed as $\mathrm{COO}$ and/or president approximately two years (1.89 years) before the planned departure. This finding indicates that when a CEO nears retirement, he/she may appoint the potential successor as the $\mathrm{COO}$ and/or president, as part of the "grooming" process. Second, the new CEO candidates are appointed as a board of director two to three years in advance in firms with planned departure. Particularly, in the planned departure subsample, more than two-third (35.7\%) of the new CEOs were appointed as directors two years prior, and nearly $50 \%$ of the new CEOs joined the board one year prior to the power transition.

On the other hand, there is no evidence of "grooming" or "preparing" in firms with unexpected CEO departures. Not only are these firms less likely to use relay successions, should a COO or president be promoted to CEO after an unexpected departure, my findings show that they have been in the $\mathrm{COO} /$ president position for at least four years prior to the departure. Additionally, new CEOs have been on the board long before the succession. Nearly $90 \%$ of the new CEOs have been a director for at least 3.5 years prior to the incumbent CEO's departure. These findings suggest that when faced with an unexpected CEO departure when the incumbent CEOs are no longer involved in the succession process and when there is less time to plan for succession, firms tend to appoint a successor with lengthy firm and board experience to weather the storm.

This paper fills the gap in the CEO succession planning literature by investigating whether and how lead time in CEO succession matters. To my knowledge, this is the first paper to use lead time as a proxy for the time firms have to plan for succession to compensate for the lack of direct evidence of succession planning and to evaluate the relationship between succession planning and disruption costs associated with the power transition. Extant literature has yet to identify the process of CEO succession planning or the actual costs associated with not having sufficient time to plan for the CEO leadership transition. The findings of this paper show that both the incumbent CEOs' involvement in the succession process and having a plan in place could contribute to a smooth transition. This paper also shed lights on the actions firms make to their boards to prepare for the power transition prior to a CEO departure. My findings indicate that the new CEO candidate is more likely to be the heir apparent and usually appointed to the board approximately two years in advance prior to the planned departure to smooth transition. 
The findings in this paper are of particular importance in light of the new SEC requirement regarding CEO succession planning (see SEC Staff Legal Bulletin 14E, 2009). Indeed, survey data (Note 3) reveals a surprisingly lack of preparedness for top leadership transitions in US companies. For instance, only about half $(51 \%)$ of survey respondents could name a permanent successor if needed, and 39\% reported that they had zero viable internal candidates. If CEO succession matters, perhaps firms need to be better equipped and have a succession plan in place to ensure a smoother transition, especially when faced with unexpected CEO departures. My findings show that succession planning could save firms approximately \$136 million during the leadership transition period, therefore lend support to the new SEC recommendation. CEO succession planning should, indeed, be elevated to a core aspect of a firm's corporate governance regime.

The remainder of the paper is organized as follows. Section 2 discusses the prior literature and develops my hypotheses. Section 3 describes the data and provides summary statistics. Section 4 and 5 present univariate and multivariate results of the relationship between lead time and disruption costs. Section 6 shows the changes firms make to prepare for succession. Section 7 provides a summary and conclusion.

\section{Prior Literature and Hypotheses Development}

\subsection{Importance of CEO Succession Planning}

Since it is difficult to disentangle whether firms have a succession planning in place, existing literature on the importance of succession planning has mainly focused on shareholder reactions and changes in firm performance around the sudden/unexpected death of the CEO or other senior managers. Studies as early as Johnson, Magee, Nagrajan, and Newman (1985) examine the relationship between CEO death and shareholder wealth through announcement returns. They find that senior executive sudden death may have different impact on shareholder wealth, depending upon the characteristics of employment relationship of the passing and replacing executives. The net excess return is positively associated with the passing of a founder CEO, and negatively associated with the passing executive's position other than founder in the company.

Worrell, Davidson III, Chandy and Garrison (1986) attempt to investigate the consequence of senior executive turnover by examining announcement returns of death. They find that shareholders are indifferent towards general senior executive death, but react negatively if the CEO died, if death is sudden, and if founder died. And they react positively towards chairman death (chairmen in their sample were in the age of 70s, 80s, and 90s).

Behn, Dawley, Riley and Yang (2006) find that delay in appointing a successor after unexpected senior executive death is associated with decreasing operating performance, measured by change in sales, change in income before extraordinary items scaled by sales, calculated over one-year and two-year period, and lower cumulative returns around the death of the CEO. In a more recent paper, Salas 2010 argues that stock price reaction towards senior executive sudden death could be a proxy of entrenchment. Positive shareholder reaction may indicate death removed entrenched management, yet negative reaction may indicate the passing of a highly effective and hard to replace executive.

McConnell and Qi (2016) state that succession planning is beneficial and enhances firm performance. In addition, in the framework of CEO-firm match theory, the CEO labor market is competitive and efficient and the matching between CEOs and firms is optimal. Jenter et al. (2016) argue that in a frictionless CEO labor market, the match between a firm and its CEO is ideal and when one CEO dies, firms select the next best CEO. Therefore, CEO death should not improve firm value. However, frictions such as information asymmetry between the candidates and the firm as well as transitional cost can delay the board in finding the best candidate and in transitioning the firm's leadership. Both empirical and anecdotal evidence show that there exists friction in the CEO firm matching process.

In general, prior studies find that sudden/unexpected CEO departures are detrimental to shareholder wealth. When faced with sudden/unexpected CEO departures, firms and their boards may not have sufficient time to compose a succession plan, hence experience higher disruption costs reflected by negative shareholder reactions. I predict that firms with planned departure may experience lower disruption costs partially proxied by short-term cumulative market-adjusted stock performance.

\subsection{Succession Type and Outcome}

Prior literature categorizes CEO succession into relay, horse race, or outside succession based on whether there exists an heir apparent successor (Canalla and Shen 2001, Shen and Canalla Jr. 2003, Zhang and Rajagopalan 2004, Behn, Riley Jr. and Yang 2005). A firm is identified to have an heir apparent if an executive is holding the title of $\mathrm{COO}$ and/or president. Behn et al. (2005) uses heir apparent successor to proxy for CEO succession planning, and find that shareholders react less negatively at the announcement of sudden CEO death if firms have identified an heir 
apparent. The authors then argue that CEO succession planning seems to add value to companies engaged in the transition of power.

Shen and Cannella Jr (2003A) find that shareholders prefer heir succession to non-heir inside succession. In addition, outside successions are associated with poorer firm performance and positive announcement returns, reflecting shareholders' dissatisfaction towards the incumbent CEO and desire for a change in firm management. However, the authors recommend that firms carefully select and groom heirs, and monitor them first. If firm performance continues to be good, firms should ensure promotion. If not, then board of directors should consider outside succession. Shen and Cannella Jr (2003B) also specifically examine relay succession. Their findings suggest that shareholders prefer relay succession over non-relay succession. Although there is insignificant stock price reaction towards the initiation of heir apparent appointment, shareholders react positively towards the promotion, and negatively towards the departure. Outside succession is also associated with a positive stock price reaction.

Zhang and Rajaopalan (2004) also find relay succession to add value. Specifically, they find that relay succession is associated with higher pre and post succession firm performance. However, the more internal candidates in a firm, the lower the likelihood of relay succession. Firms may opt for horse race succession when there are more qualified internal candidates. In a more recent paper, Mobbs and Raheja (2012) argue that succession planning is not one-type-fits-all, compared to tournaments promotion (horse race), successor-incentive promotion is associated with higher pay-for-performance sensitivity to the designated successor. They authors find that relay successions are more common in firms or industries where firm specific knowledge is more important to the CEO position and where the supply of potential outside CEO replacements is limited.

A few papers have attempted to investigate the importance of CEO succession planning by examining shareholder reactions during heir apparent successions. For instance, Behn, Riley Jr. and Yang (2005) examine whether shareholders value firms with a succession plan in place. Specifically, they use whether firms have an heir apparent (i.e. an officer holding the title of $\mathrm{COO}$ and/or President and is at least five years younger than the incumbent CEO) as a proxy for succession planning and investigate shareholder reactions at the announcement of a sudden CEO death. The authors find that the cumulative announcement returns on the date of death are higher in firms with an heir apparent successor. The major difference between my paper and Behn et al. (2005) is that I use a much cleaner proxy for succession by hand collecting firms with a clear indication of planned CEO departure. The issue with using general CEO turnover event to examine the importance of CEO succession planning is that shareholder reactions are impacted by the cause of turnovers. For instance, after a forced CEO turnover, it will be difficult to disentangle whether shareholders react positively because the company may have a succession plan in place or because it fired an incompetent CEO.

Overall, firms with a succession plan in place seem more likely to use relay successions. I predict that firms with planned departure have longer lead time and are more likely to use relay successions. Presumably a longer-lead time may allow firms to compose a plan and start grooming an heir apparent, even if there is no plan in place. Longer lead time may also allow firms to have lower disruption costs and smoother transition.

\section{Data and Summary Statistics}

I use data from eight different sources. I first identify the initial sample of CEO departures during the period 1991-2009 from Execucomp, which covers S\&P 1500 firms. CRSP and Compustat provide stock returns and accounting information. CEO successor board experience and corporate governance data are identified through the Investor Responsibility Research Center (IRRC) Director Database (Note 4). Institutional ownership information is obtained through Thomson Reuters Institutional Ownership Data. I hand collect data to fill in any observations where CEO appointment date or the date he/she joined the company is missing in Execucomp, for the purpose of identifying CEO tenure.

For all CEO departures covered in Execucomp, I use Factiva, Lexis Nexis and proxy statements to hand collect the following information: (1) CEO successor origin. This information is missing for some observations due to the missing data in Execucomp on the date the CEO joined the company. I follow Parrino's (1997) definition on insider versus outsiders. Insiders are successors that have been with the company for at least one year prior to becoming CEO; and outsiders are successors that have been with the company for less than a year prior to becoming CEO. (2) Interim CEOs. Whether the news release states that the successor is an interim or permanent CEO. (3) Cause of departure. I categorize the departure of the CEO into natural retirement, forced resignation, unexpected departures, M\&A activity, restructuring, proxy fight, and the separation of CEO/chairman duality. (4) The earliest announcement date of incumbent CEO departure and permanent replacement CEO appointment. (5) The actual incumbent CEO departure and new CEO takeover date. (6) Whether the replacement CEO has been on the 
appointing company's board of directors at least six months before the appointment announcement. (7) Cause of the unexpected departure. Whether the unexpected departure is due to sudden death, illness, or is due to incumbent CEO being hired away either by a better company, or accepted a government job. (8) Whether the replacement CEO has had CEO experience before in other companies. (9) Whether the retiring CEO is the founder of the company, and whether the company is a family company. (10) The previous positions held by replacement CEOs.

After collecting data for the whole CEO departure sample, I narrow my focus onto planned departures and unexpected CEO departures. A CEO departure is categorized as a planned departure if the incumbent CEOs' departure announcement contains key terms indicating that the departure is part of an orderly transition of power. The key terms include "succession", "succession planning", "succession plan", "natural transition", "retirement age, "retirement", "required retirement" and" orderly transition of power. A CEO departure is categorized as unexpected when the CEO departure (or decision to leave) is neither a result of poor performance, nor of regulatory and/or criminal investigation. It should be a genuinely unexpected event. Although a CEO's departure may have come to a surprise to the market, it will not be included in my sample if the board was aware of the departure (or decision to leave), or if it was under the mutual agreement between the CEO and the board. The final sample consists of 921 CEO departures, out of which 843 are planned departure and 78 are unexpected departures from 1999 to 2008 (Note $5)$.

Following prior literature, I used three measures to proxy disruption costs: (1) cumulative market-adjusted stock returns around the departure announcement. (2) change in sales from one year before to three years after the departure announcement. (3) Change in firm operating performance from one year before to three years after the incumbent CEO departure announcement. I use two measures of firm operating performance. The first is the industry-adjusted ROA, measured as a sample firm's ROA minus the median industry ROA, using the Fama and French (1997) 48-industry classification (results not tabulated). To control for potential mean reversion in accounting returns for poorly performing firms, I follow the methodology of Barber and Lyon (1996) to compute changes in industry-and-performance adjusted ROA. Each sample firm with a sudden CEO departure is matched to a control firm with no CEO departures. Industry-and-performance adjusted ROA is then defined as each sample firm's ROA less the ROA of a control firm, matched on primary two-digit SIC industry and with the ROA within 10\% in the previous year. If no firm in the same two-digit industry has a year-1 ROA within $10 \%$, I first select the firm in the same one- digit industry, and then disregard industry and only match on year-1 ROA within $10 \%$.

\section{Univariate Analysis}

\subsection{CEO Departures Through Time}

Table 1 shows the distribution of planned and unexpected CEO departures during the period of 1999 to 2008. Departing CEO age information is from Execucomp and may not be available for all observations. Lead time is the number of days between the incumbent CEO's departure announcement date and their actual departure date.

Table 1. Summary of planned retirement and unexpected CEO departure by time

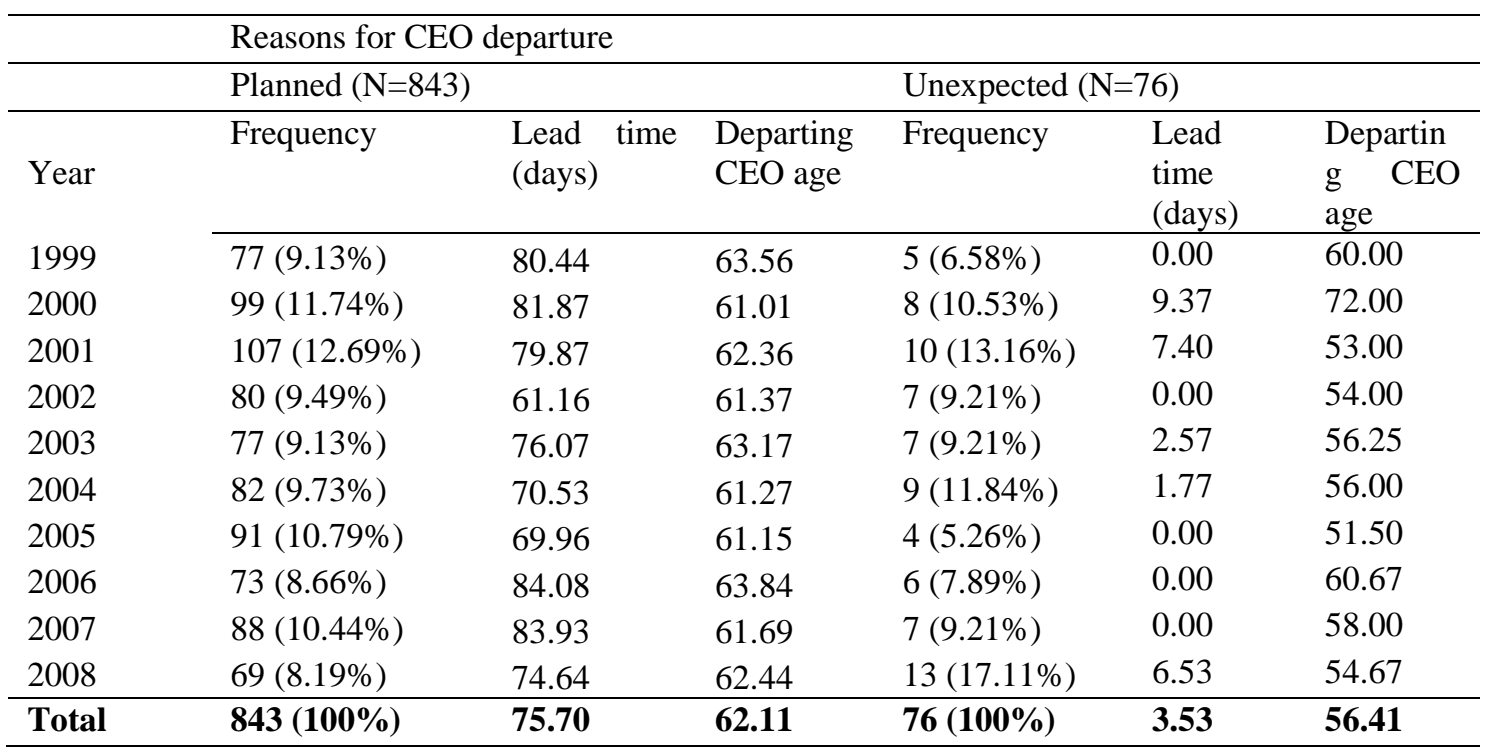


Table 1 shows both planned departure and unexpected CEO departures through time from 1999 to 2008. I also tabulate lead time and departing CEO age. There seems to be no systematic clustering over time. Both planned and unexpected CEO departures are randomly distributed through time. However, there is a fairly strong difference in lead time between the two subsamples.

Figure 1 shows the time line for firms with planned CEO departures. Lead time is the number of days between the first public announcement of CEO departure and the actual departure date. The average lead time is 75.70 days for firms with planned retirement.

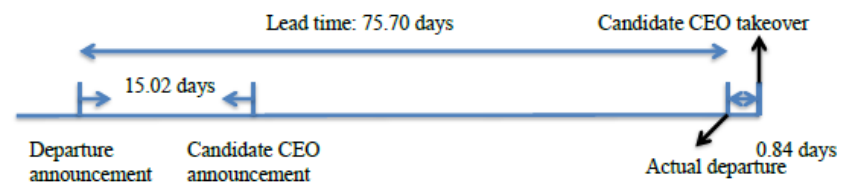

Figure 1. Time line of planned retirement

Figure 2 shows the time line for firms with unexpected CEO departures. Lead time is the number of days between the first public announcement of CEO departure and the actual departure date. The average lead time for firms with unexpected CEO departures are 3.53 days.

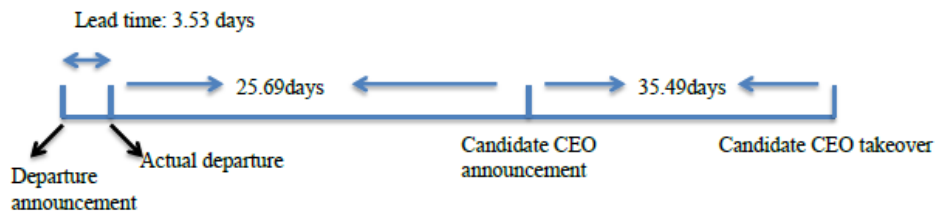

Figure 2. Time line of unexpected CEO departures

On average, firms have a 76-day lead time when the incumbent CEO plans to retire; whereas when faced with an unexpected CEO departure, firms only have a 3.5-day lead time. In addition to lead time, there is also a difference in departing CEO age between the two subsamples. CEOs typically near retirement age (reference) of 62-65 in the planned departure subsample. On the other hand, the age of CEOs unexpected left the firm ranges from 51 to 75 , indicating that unexpected departures happen fairly randomly across difference age groups.

\subsection{Descriptive Statistics in Firms With Planned Departure and Unexpected CEO Departures}

Table 2 shows the univariate comparison of firm, corporate governance and departing CEO characteristics. The mean values of each variable are followed by mean differences between subsamples of firms with planned and unexpected CEO departures. $* * *, * *$, and $*$ indicate that the mean is significantly different from 0 at $1 \%, 5 \%$, and $10 \%$ level. Bolded letters and $c, b$, and $a$ indicate a two-sided t-test for mean differences between subsamples of Planned retirement and unexpected CEO departures are significant at 1\%, 5\% and 10\% level. The definition of all other variables is in the Appendix. Note: information on some variables may not be available for the whole sample period.

Table 2. Firm, corporate governance, and departing CEO characteristics

\begin{tabular}{lllllll}
\hline & $\begin{array}{l}\text { Planned } \\
\text { retiremen } \\
\mathrm{t}\end{array}$ & $\begin{array}{l}\text { Above } \\
\text { median } \\
\text { lead time } \\
(\mathrm{N}=843)\end{array}$ & $\begin{array}{l}\text { Below } \\
\text { median } \\
\text { lead time } \\
(\mathrm{N}=420)\end{array}$ & $\begin{array}{l}\text { Unexpect-ed } \\
(\mathrm{N}=76)\end{array}$ & $\begin{array}{l}\text { Mean Diff } \\
(1) \text { and (4) }\end{array}$ & $\begin{array}{l}\text { Mean Diff } \\
(2) \text { and (4) }\end{array}$ \\
\cline { 2 - 7 } Firm characteristics & 24.24 & 25.92 & 22.63 & 22.41 & 1.83 & $\mathbf{3 . 5 2}^{\mathbf{a}}$ \\
Firm age & 2.79 & 2.88 & 2.74 & 2.48 & 0.31 & 0.39 \\
Tobin's Q & 10,273 & 13,022 & 7,728 & 5,717 & 4,556 & $\mathbf{7 , 3 0 5}^{\mathbf{a}}$ \\
Market Cap (000,000) & $2.37 \%$ & $2.20 \%$ & $2.54 \%$ & $2.97 \%$ & $-0.60 \%$ & $0.73 \%$
\end{tabular}




\begin{tabular}{|c|c|c|c|c|c|c|}
\hline Leverage & $22.68 \%$ & $22.99 \%$ & $22.34 \%$ & $22.20 \%$ & $0.40 \%$ & $0.79 \%$ \\
\hline Free cash flow & $4.12 \%$ & $4.43 \%$ & $3.80 \%$ & $2.42 \%$ & $1.70 \%{ }^{a}$ & $2.01 \%{ }^{a}$ \\
\hline Firm risk $_{t-1}$ & $2.51 \%$ & $2.34 \%$ & $2.68 \%$ & $2.67 \%$ & $-0.16 \%$ & $-0.32 \%{ }^{a}$ \\
\hline Industry adjusted $\mathrm{ROA}_{t-1}$ & $4.87 \%$ & $5.35 \%$ & $4.43 \%$ & $4.47 \%$ & $0.40 \%$ & $0.96 \%$ \\
\hline Market to book ratio & 1.42 & 1.44 & 1.44 & 1.38 & 0.04 & 0.06 \\
\hline \multicolumn{7}{|l|}{ orporate Governance } \\
\hline Institutional ownership & $64.68 \%$ & $64.25 \%$ & $60.99 \%$ & $64.04 \%$ & $0.64 \%$ & $0.21 \%$ \\
\hline Board size & 10.01 & 10.34 & 9.60 & 9.67 & 0.34 & $0.67^{\mathrm{a}}$ \\
\hline Board independence & $67.45 \%$ & $69.48 \%$ & $65.00 \%$ & $68.67 \%$ & $-1.22 \%$ & $0.81 \%$ \\
\hline Departing CEO founder & $9.63 \%$ & $7.14 \%$ & $12.63 \%$ & $9.21 \%$ & $0.42 \%$ & $-2.07 \%$ \\
\hline
\end{tabular}

Table 2 provides summary statistics of firm, departing CEO, and corporate governance characteristics on firms with planned departure and unexpected CEO departures. With the planned retirement subsample, I further compare firms with above and below-median lead time. The results show that there is no systematic difference between firms with planned retirement and those with unexpected departures. One exception is the free cash flows. Firms with planned departure have greater Free Cash Flow (FCF) (4.12\% versus $2.58 \%$ ) compared to firms with unexpected CEO departures. Prior literature uses Free Cash Flow (FCF) as a measure of managerial discretion on the use of internally generated cash flows (Jensen 1986, Stulz 1990, Richardson 2006, Chen Chen and Wei 2011). Therefore it is possible that managers in firms with planned retirement have greater managerial discretion over its cash flows, compare to their counter parties in firms with unexpected CEO departures. Albeit not a measure of the actual length and depth of the succession planning process, I argue that firms with above-median lead time are most likely to have a succession plan in place, compared to firms with below-median lead time and firms with unexpected CEO departures. Therefore, I compare firms with above-median lead time to firms with unexpected CEO departures. I find that firms with above-median lead time are significantly older, more mature firms with greater FCF and lower stock price volatility. These firms also have bigger boards. Overall, these results indicate that larger, more mature firms may be more likely to have a succession plan in place when the incumbent CEO is near retirement in the near future.

4.3 Comparison of Disruption/Transitional Characteristics Between Firms With Planned Departure and Unexpected CEO Departures

Table 3 shows the univariate comparison of CEO transitional characteristics and disruption costs between firms with Planned retirement and unexpected CEO departures. Panel A shows the comparison of CEO transitional characteristics. Lead time is the number of days between the incumbent CEO's departure announcement date and their actual departure date. Days before new CEO takeover is the number of days between the incumbent CEOs' departure announcement date and actual date the new CEO takes over. Days without leadership is the number of days firms operate without CEO leadership.. Relay succession is an indicator variable that equals to 1 if the new $\mathrm{CEO}$ has been the $\mathrm{COO}$ and/or President before they were promoted and the new CEO is least five years younger than the incumbent CEO. Days since new CEO apt COO/President is the executive tenure as COO and/or President. Panel $\mathrm{B}$ shows the comparison of market reaction (cumulative abnormal returns) three days around the announcement of the incumbent CEO departure, as well as excess stock returns within 30 days after the incumbent CEOs' actual departure date. The announcement CARs are computed in Eventus using both market adjusted (untabulated) and market model, and the excess returns are the market-adjusted cumulative stock returns within 30 days of actual departure date. Stock return data is from CRSP. Definitions of all other variables are in the Appendix. ***,**, and * indicate that the mean is significantly different from 0 at $1 \%, 5 \%$, and $10 \%$ level. Bolded letters $c, b$, and $a$ indicate a two-sided t-test for mean differences between Planned retirement and unexpected CEO departure subsamples are significant at $1 \%, 5 \%$ and $10 \%$ level. Changes in performance are winsorized at $1 \%$. 
Table 3. Comparison of transitional characteristics and disruption costs between planned and unexpected CEO departures

Panel A. Comparison of CEO transitional characteristics

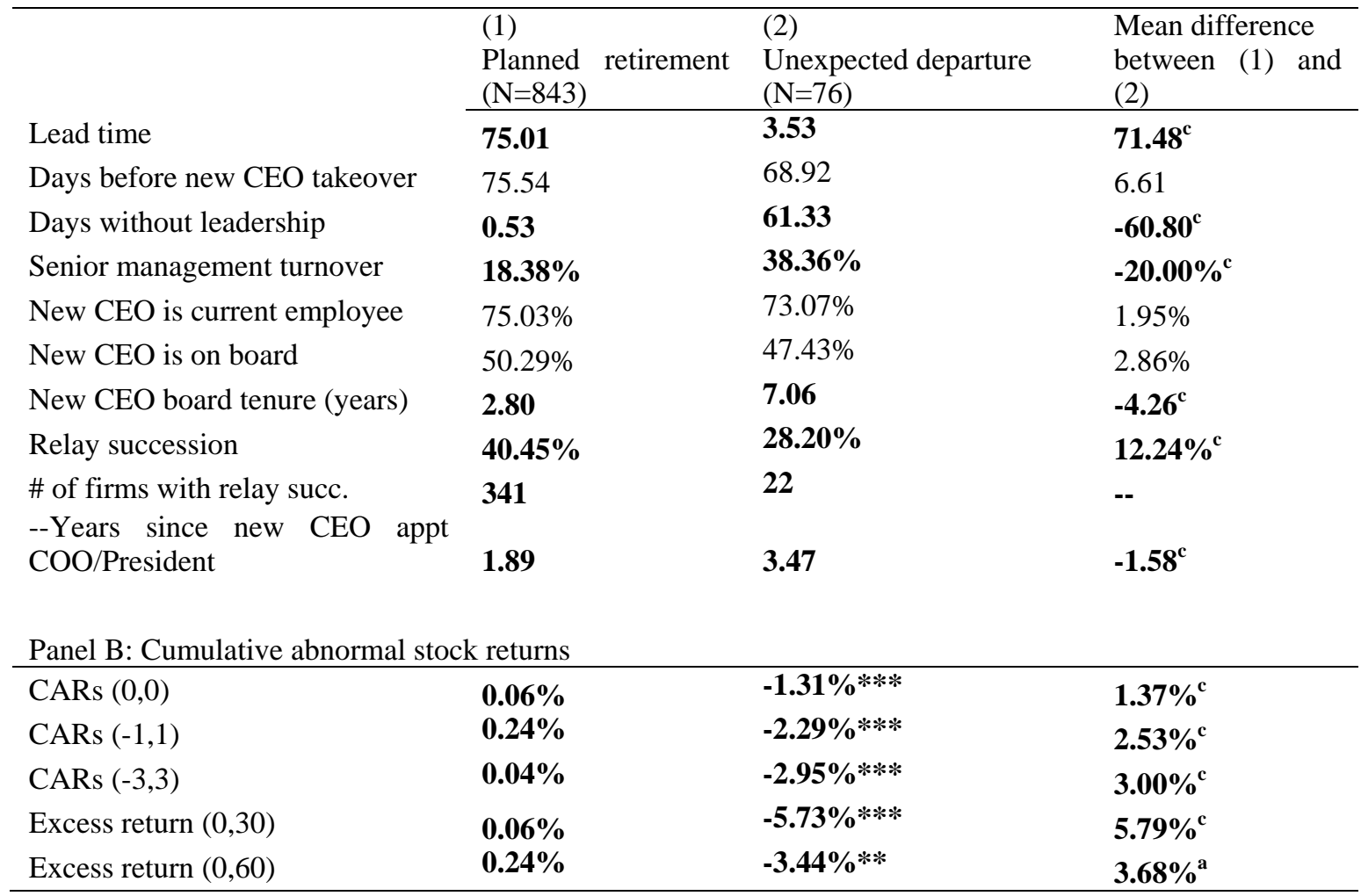

Panel A in Table 3 shows the comparison of CEO transitional characteristics between firms with planned departure and unexpected CEO departures. The delay between incumbent CEOs' departure announcement date and their actual departure date (lead time) is 75.70 days when the departure is planned. On the other hand, when the departure is unexpected due to death, illness, and sudden resignation, lead time is significantly shorter at 3.53 days. This result is consistent with my prediction that firms with unexpected departures may have shorter lead time, hence are less likely to plan for succession given the suddenness of the CEO departure. Another interesting result is that on the same day the incumbent CEO leaves a firm, a new CEO will take over, hence the time a firms does not have CEO leadership is zero when the retirement is planned in advance. However, firms with unexpected CEO departure experience approximately 61 days without a CEO in place, measured by the difference between days before new CEO takeover and lead time.

Although lead time proxies the likelihood either CEO succession plan in place or succession planning, it may not be an accurate measure for how long firms have been succession planning. An alternative measure for the length of succession planning, particularly relay succession, is the number of days since the new CEO was appointed as a $\mathrm{COO}$ and/or President. I hand-collect the date the new CEO was appointed to the position of COO and/or President from Lexis-Nexis and Factiva for firms who seemingly implemented relay succession. Anecdotal evidence indicates that firms typically appoint the heir apparent to the COO/President position one or two years in advance for "grooming" purpose. The two-year period will allow the new CEO candidate gain hands-on experience firms" day-to-day operations, and build relationships with the board of directors and other senior managers. Consider, for instance, the recent CEO power transition in Ford Motor Co. Ford announced on April 21, 2014 that it is to name Mark Field as the new CEO, effective on July 1. News release reported "Fields emerged as Mulally's likely successor when he was promoted to COO in December 2012. Ford had said that Mulally would stay through 2014" (Note 6). Consistent with Ford Motor's example, I find that 341(40.45\%) companies with planned departure used relay succession. The average "grooming period" is 692.72 days, approximately two years, before the COO and/or President becomes the new CEO. Yet this is little evidence of "grooming" in firms with unexpected CEO departures. Not only are these firms less likely to use relay succession (28.20\%), if a COO/President was appointed as the new CEO, their tenure as the COO/President is between three and four years. Similarly, the new CEOs have board tenure of 2.8 years in firms with planned departure, compared to 7.06 years in those with unexpected CEO departures. 
These findings indicate that when firms are faced with a shock such as the unexpected departure of its CEO, they tend to appoint executives who are familiar to operating and have longer board tenure to weather the storm.

Panel B in Table 3 provides comparison of shareholder reactions at the announcement of incumbent CEO departures. I use Eventus to generate cumulative abnormal returns (CARs) three days around the first public departure announcement using both the market model and market adjusted returns (not tabulated). For the cumulative returns up to 90 days after the departure announcement, I use valuated market adjusted returns from CRSP. Consistent with planning, when the incumbent CEOs' departure may not come as a surprise for shareholders, shareholders react insignificantly at the announcement of planned retirement. In contrast, shareholders react significantly negatively $(\mathrm{p}<=0.01)$ at the announcement of unexpected CEO departures. This negative reaction may reflect investor uncertainty towards the future of a company when its CEO left due to death, illness and sudden resignation. The differences in shareholder reaction at the departure announcement are statistically significant at $1 \%$ level between the two subsamples.

\subsection{The Costs of No Lead Time in CEO Succession}

The recent SEC Staff Legal Bulletin 14E suggests firms to disclose detailed succession planning information in their proxy statement. Some may argue that CEO succession planning is not free and can be costly. Therefore, certain firms may be better off not having a plan in place if the cost outweighs the benefit of planning for succession. In this section, I analyze the actual costs associated with little lead time to plan for succession. Table 4 shows the results of this analysis.

Table 4 shows the cost of not having much time planning for CEO succession. This cost is calculated as the dollar change in firm value associated first public announcement of CEO departure. CARs are cumulative abnormal returns three days around the first public announcement of CEO departure. Avg. CARs are the average CAR across the three event windows $(0,0),(-1,1)$, and $(-3,3)$. Market cap $t_{t-1}$ is the market capitalization of the firms measured in the year before the fiscal year of CEO departures. \$ of change in value is the product of Avg. CARs and Market Capt-1, it captures the change in firm value associated with CEO departures. Board of director compensation measures the hourly compensation paid to directors as a whole for the meeting and discussion of CEO succession related issues. According to the most recent survey data (Note 7), CEO succession plans are reviewed from once to four times a year at board meetings, and the mean (median) time (in hours) directors spend on discussing succession planning related issues is 1.14 (1.00) hours. On average, each director is compensated $\$ 1,000$ per hour to fulfill their fiduciary duties (Note 8), and the average board size is 10 directors (Coles, Daniel and Naveen 2008). The accumulated costs firms encounter to compensate board of director in CEO succession related discussions will range from $\$ 10,000$ to $\$ 40,000$. I argue that this cost is negligible for S\&P 1500 companies in my sample. Therefore, the cost associated with not planning for succession is calculated as the difference in changes in firm value between firms with planned and unexpected CEO departures. This number is captured by the variable $\Delta$ due to planning. Definitions of all other variables are in the Appendix. $* * *, * *$, and $*$ indicate that the mean is significantly different from 0 at $1 \%, 5 \%$, and $10 \%$ level.

Table 4. The cost of no lead time in CEO succession

\begin{tabular}{|c|c|c|c|c|c|}
\hline $\begin{array}{l}\text { Reasons } \\
\text { departure }\end{array}$ & CARs & $\begin{array}{l}\text { Avg.CAR } \\
\mathrm{s}\end{array}$ & $\begin{array}{l}\text { Market } \\
\text { cap } p_{t-1} \\
(000,000)\end{array}$ & $\begin{array}{l}\$ \text { of change in } \\
\text { value } \\
(000,000)\end{array}$ & $\begin{array}{l}\text { Board of } \\
\text { director } \\
\text { compensation }\end{array}$ \\
\hline \multirow[t]{3}{*}{ Planned } & $0.06 \%(0,0)$ & \multirow{3}{*}{$0.11 \%$} & \multirow{3}{*}{10,273} & \multirow{3}{*}{11.30} & \multirow{3}{*}{$\begin{array}{l}\$ 10,000-\$ 40,00 \\
0\end{array}$} \\
\hline & $0.24 \%(-1,1)$ & & & & \\
\hline & $0.04 \%(-3,3)$ & & & & \\
\hline \multirow[t]{3}{*}{ Unexpected } & $-1.31 \% * * *(0,0)$ & \multirow{3}{*}{$-2.18 \%$} & \multirow{3}{*}{5,717} & \multirow{3}{*}{-124.63} & \multirow{3}{*}{$\begin{array}{l}\$ 10,000-\$ 40,00 \\
0\end{array}$} \\
\hline & $-2.29 \% * * *(-1,1)$ & & & & \\
\hline & $-2.95 \% * * *(-3,3)$ & & & & \\
\hline
\end{tabular}

$\Delta$ due to planning $=|-124.63-11.30|=\$ 135.93(\mathrm{mln})$

The average CARs around the first public announcement are $0.11 \%$ (not statistically significant from 0 ) and $-2.18 \%$ (statistically significant from 0 at the 1\% level), for planned retirement and unexpected CEO departures, respectively. The average market capitalization for the two subsamples of firms are \$10,273 million and \$5,717 million. I then multiply the average market capitalization with the average CARs to evaluate the dollar changes in firm value 
associated with the CEO departure announcement. For firms with planned retirement, the dollar change in firm value is $\$ 11.30$ million; whereas for firms with unexpected CEO departure, the change in firm value is $-\$ 135.93$ million.

In addition to the dollar change in firm value associated with the departure announcement, firms also have to consider costs in the form of board of director compensation every time CEO succession plans is reviewed. According to the most recent survey data (Note 9), CEO succession plans are reviewed from once to four times a year at board meetings, and the mean (median) time (in hours) directors spend on discussing succession planning related issues is 1.14 (1.00) hours. On average, each director is compensated $\$ 1,000$ per hour to fulfill their fiduciary duties (Note 10), and the average board size is 10 directors (Coles, Daniel and Naveen 2008). The accumulated costs firms encounter to compensate board of director in CEO succession related discussions will range from $\$ 10,000$ to $\$ 40,000$ per hour per firm. I argue that this cost is negligible for S\&P 1500 companies in my sample. Therefore, the cost associated with not having much lead time to plan for succession is calculated as the difference in changes in firm value between firms with planned and unexpected CEO departures. This difference rounds up to $\$ 136$ million if the CEO departs unexpectedly. Given the large magnitude of the change in firm value associated with a lack of lead time, I argue that it is doubtful that the costs of not planning for succession will outweigh the benefits. Although it is not the intention of this paper to investigate whether all firms should have a succession plan, it will certainly be interesting for future research to examine why firms will choose to not plan for succession, and what types of firms benefit the most from having a succession plan.

\section{Multivariate Analysis}

\subsection{Cumulative Abnormal Stock Returns After the Incumbent Ceos' Actual Departure Date}

Table 5 shows the estimate of OLS regressions of the cumulative abnormal returns (CARs) within event windows $(0$, $0),(-1,1),(-3,3)$ and excess stock returns within 30 days after the incumbent CEOs' actual departure date. The dependent variables are value-weighted-market-adjusted excess stock returns. Unexpected CEO departure is a binary variable that equals to 1 if the CEO departure is caused by unexpected event, including death, sudden illness and sudden resignation, and 0 otherwise. Non heir apparent succession is also a binary variable that equals to 1 if firms implemented horse race succession (allowing internal candidate to compete for the CEO position) or outside succession, and 0 if firms appointed an heir apparent. All dependent variables are in the percentage format. ***, **, and $*$ indicate statistical significance at the $1 \%, 5 \%$, and $10 \%$ level, respectively. p-values are reported in the parentheses.

Table 5. Multivariate analysis on excess stock returns around incumbent CEO departure

Panel A. Regression using the whole sample

\begin{tabular}{|c|c|c|c|c|c|c|c|c|}
\hline Independent variables & $\begin{array}{l}\text { (1) CARs } \\
(0,0) \\
(\%)\end{array}$ & $\begin{array}{l}\text { (2) CARs } \\
(0,0) \\
(\%)\end{array}$ & $\begin{array}{l}\text { (3) CARs } \\
(-1,1)(\%)\end{array}$ & $\begin{array}{l}\text { (4) CARs } \\
(-1,1)(\%)\end{array}$ & $\begin{array}{l}(5) \text { CARs } \\
(-3,3)(\%)\end{array}$ & $\begin{array}{l}\text { (6) CARs } \\
(-3,3)(\%)\end{array}$ & $\begin{array}{l}\text { (7) Excess } \\
\text { retum } \\
(0,30)(\%)\end{array}$ & $\begin{array}{l}(8) \text { Excess } \\
\text { return } \\
(0,30)(\%)\end{array}$ \\
\hline Unexpected departure & $\begin{array}{l}-1.790^{* \pi *} \\
(0.00)\end{array}$ & $\begin{array}{l}-1.200 \\
(0.20)\end{array}$ & $\begin{array}{l}-2.960^{* \star *} \\
(0.00)\end{array}$ & $\begin{array}{l}-1.420 \\
(0.18)\end{array}$ & $\begin{array}{l}-3.290^{* \ldots \hbar} \\
(0.00)\end{array}$ & $\begin{array}{l}-2.010^{*} \\
(0.10)\end{array}$ & $\begin{array}{l}-6.290^{* \hbar \hbar} \\
(0.00)\end{array}$ & $\begin{array}{l}-3.860^{*} \\
(0.06)\end{array}$ \\
\hline Non heir apparent succession & $\begin{array}{l}0.004 \\
(0.81)\end{array}$ & $\begin{array}{l}0.145 \\
(0.94)\end{array}$ & $\begin{array}{l}0.045 \\
(0.49)\end{array}$ & $\begin{array}{l}0.232 \\
(0.32)\end{array}$ & $\begin{array}{l}0.174 \\
(0.86)\end{array}$ & $\begin{array}{l}0.328 \\
(0.85)\end{array}$ & $\begin{array}{l}1.570^{* *} \\
(0.05)\end{array}$ & $\begin{array}{l}1.860^{* *} \\
(0.03)\end{array}$ \\
\hline $\begin{array}{l}\text { Unexpected departure } \\
\text { * Non heir apparent succession }\end{array}$ & & $\begin{array}{l}-1.510 \\
(0.23)\end{array}$ & & $\begin{array}{l}-2.790^{*} \\
(0.09)\end{array}$ & & $\begin{array}{l}-2.310^{*} \\
(0.09)\end{array}$ & & $\begin{array}{l}-4.380^{*} \\
(0.08)\end{array}$ \\
\hline Log (Market cap) & $\begin{array}{l}0.083 \\
(0.28)\end{array}$ & $\begin{array}{l}0.081 \\
(0.26)\end{array}$ & $\begin{array}{l}0.156 \\
(0.28)\end{array}$ & $\begin{array}{l}0.149 \\
(0.30)\end{array}$ & $\begin{array}{l}0.161 \\
(0.44)\end{array}$ & $\begin{array}{l}0.150 \\
(0.47)\end{array}$ & $\begin{array}{l}0.212 \\
(0.51)\end{array}$ & $\begin{array}{l}0.196 \\
(0.54)\end{array}$ \\
\hline Founder CEO & $\begin{array}{l}0.183 \\
(0.66)\end{array}$ & $\begin{array}{l}-0.173 \\
(0.67)\end{array}$ & $\begin{array}{l}-0.223 \\
(0.73)\end{array}$ & $\begin{array}{l}-0.184 \\
(0.96)\end{array}$ & $\begin{array}{l}1.280 \\
(0.20)\end{array}$ & $\begin{array}{l}1.340 \\
(0.18)\end{array}$ & $\begin{array}{l}0.742 \\
(0.67)\end{array}$ & $\begin{array}{l}0.840 \\
(0.65)\end{array}$ \\
\hline Firm risk (\%) & $\begin{array}{l}0.128 \\
(0.48)\end{array}$ & $\begin{array}{l}0.122 \\
(0.50)\end{array}$ & $\begin{array}{l}0.369 \\
(0.26)\end{array}$ & $\begin{array}{l}0.346 \\
(0.29)\end{array}$ & $\begin{array}{l}0.357 \\
(0.43)\end{array}$ & $\begin{array}{l}0.319 \\
(0.48)\end{array}$ & $\begin{array}{l}0.221 \\
(0.75)\end{array}$ & $\begin{array}{l}0.162 \\
(0.82)\end{array}$ \\
\hline R\&D intensity (\%) & $\begin{array}{l}-0.028 \\
(0.47)\end{array}$ & $\begin{array}{l}-0.028 \\
(0.47)\end{array}$ & $\begin{array}{l}0.079 \\
(0.33)\end{array}$ & $\begin{array}{l}0.078 \\
(0.57)\end{array}$ & $\begin{array}{l}-0.093 \\
(0.34)\end{array}$ & $\begin{array}{l}-0.095 \\
(0.34)\end{array}$ & $\begin{array}{l}0.089 \\
(0.57)\end{array}$ & $\begin{array}{l}0.086 \\
(0.58)\end{array}$ \\
\hline Institutional ownership (\%) & $\begin{array}{l}-0.011^{* \pi *} \\
(0.01)\end{array}$ & $\begin{array}{l}-0.012^{\text {** }} \\
(0.02)\end{array}$ & $\begin{array}{l}-0.014^{* * *} \\
(0.02)\end{array}$ & $\begin{array}{l}-0.014^{* *} \\
(0.02)\end{array}$ & $\begin{array}{l}-0.013 \\
(0.17)\end{array}$ & $\begin{array}{l}-0.013 \\
(0.18)\end{array}$ & $\begin{array}{l}0.002 \\
(0.84)\end{array}$ & $\begin{array}{l}0.002 \\
(0.82)\end{array}$ \\
\hline Prior 1yr stock return (\%) & $\begin{array}{l}0.000 \\
(0.88) \\
\end{array}$ & $\begin{array}{l}0.000 \\
(0.87) \\
\end{array}$ & $\begin{array}{l}0.003 \\
(0.49) \\
\end{array}$ & $\begin{array}{l}0.002 \\
(0.51) \\
\end{array}$ & $\begin{array}{l}-0.006 \\
(0.36) \\
\end{array}$ & $\begin{array}{l}-0.006 \\
(0.36) \\
\end{array}$ & $\begin{array}{l}0.019^{*} \\
(0.06)\end{array}$ & $\begin{array}{l}0.018^{*} \\
(0.06)\end{array}$ \\
\hline Independent variables & $\begin{array}{l}\text { (1) CARs } \\
(0,0) \\
(\%)\end{array}$ & $\begin{array}{l}\text { (2) CARs } \\
(0,0) \\
(\%)\end{array}$ & $\begin{array}{l}\text { (3) CARs } \\
(-1,1)(\%)\end{array}$ & $\begin{array}{l}\text { (4) CARs } \\
(-1,1)(\%)\end{array}$ & $\begin{array}{l}\text { (5) CARs } \\
(-3,3)(\%)\end{array}$ & $\begin{array}{l}\text { (6) CARs } \\
(-3,3)(\%)\end{array}$ & $\begin{array}{l}\text { (7) Excess } \\
\text { retum } \\
(0,30)(\%)\end{array}$ & $\begin{array}{l}(8) \text { Excess } \\
\text { retumn } \\
(0,30)(\%)\end{array}$ \\
\hline Leverage $(\%)$ & $\begin{array}{l}0.003 \\
(0.74)\end{array}$ & $\begin{array}{l}0.003 \\
(0.73)\end{array}$ & $\begin{array}{l}0.004 \\
(0.77)\end{array}$ & $\begin{array}{l}0.004 \\
(0.73)\end{array}$ & $\begin{array}{l}0.011 \\
(0.54)\end{array}$ & $\begin{array}{l}0.011 \\
(0.50)\end{array}$ & $\begin{array}{l}-0.011 \\
(0.68)\end{array}$ & $\begin{array}{l}-0.010 \\
(0.72)\end{array}$ \\
\hline Free cash flow (\%) & $\begin{array}{l}-0.013 \\
(0.53)\end{array}$ & $\begin{array}{l}-0.013 \\
(0.54)\end{array}$ & $\begin{array}{l}-0.027 \\
(0.58)\end{array}$ & $\begin{array}{l}-0.026 \\
(0.58)\end{array}$ & $\begin{array}{l}0.102 \\
(0.859)\end{array}$ & $\begin{array}{l}0.102 \\
(0.86)\end{array}$ & $\begin{array}{l}0.065 \\
(0.43)\end{array}$ & $\begin{array}{l}0.065 \\
(0.43)\end{array}$ \\
\hline $\begin{array}{l}\text { Constant, year and industry } \\
\text { dummies }\end{array}$ & Yes & Yes & Yes & Yes & Yes & Yes & Yes & Yes \\
\hline Number of observations & 901 & 901 & 901 & 901 & 901 & 901 & 901 & 901 \\
\hline R-sq & 0.051 & 0.055 & 0.049 & 0.054 & 0.039 & 0.040 & 0.047 & 0.049 \\
\hline
\end{tabular}


Univariate analysis does not control for other factors that could impact the change in stock performance. In this section, I extend my analysis to a multivariate setting. I rely on related prior studies, for instance, Yermack (1996), Naveen (2006), Coles et al. (2008), and Coles et al. (2012), for guidance in selecting control variables. Table 5 shows the multivariate analysis results on the cumulative abnormal stock returns during the event windows $(0,0),(-1,1)$, $(-3,3)$ around the first public departure announcement date, and up to 90 days after the departure announcement. The cumulative returns are calculated using market-adjusted model. I use Ordinary Least Squares (OLS) regression with the White Robustness Error, controlling for firm, corporate governance, and departing CEO characteristics. The dependent variables are all in percentage format.

The result shows that unexpected CEO departures are associated with significantly negative CARs. Specifically, a change from planned departure to unexpected departure decreases the CARs $(0,0)$, CARs $(-1,1)$, and CARs $(-3,3)$ by $1.79 \%, 2.96 \%$, and $3.29 \%$, respectively. Furthermore, it decreases the excess stock returns within a 30-day period after the departure by $6.29 \%$. These results are consistent with the univeraite analysis result. Specifically, firms with unexpected CEO departures have short lead time and experience lower abnormal stock returns around the departure announcement. In order to evaluate when and where disruption costs materialize, in regressions (2), (4), (6), and (8), I control for the interaction between the "unexpected departure" and "non heir apparent successions". Unexpected departure is a binary variable that equals to 1 if the cause of CEO departure is due to death, sudden illness, and sudden resignation, and 0 otherwise. Non heir apparent succession is also a binary variable that equals to 1 if firms either used horse race or outside succession, instead of choosing/grooming an heir apparent to be the new CEO. The results show that although these is no significant relation between the use of non heir apparent succession and abnormal stock returns, when faced with an unexpected CEO departure, firms experience significantly negative abnormal returns (on average $-2.79 \%$ to $-4.38 \%$ ) if there is no heir apparent successor. This result indicates that with a short lead time, firms may make suboptimal choices in selecting successors; therefore negatively impact shareholder confidence and stock performance.

\subsection{Change in Firm Operating Performance}

Table 6 shows the estimate of OLS regressions of changes in industry-and-performance-adjusted ROA over the period from one year before to three years after the actual departure. I use two measures of firm operating performance. The first is the industry-adjusted ROA, measured as a sample firm's ROA minus the median industry ROA, using the Fama and French (1997) 48-industry classification (results not tabulated). To control for potential mean reversion in accounting returns for poorly performing firms, I follow the methodology of Barber and Lyon (1996) to compute changes in industry-and-performance adjusted ROA. Each sample firm with a sudden CEO departure is matched to a control firm with no CEO departures. Industry-and-performance adjusted ROA is then defined as each sample firm's ROA less the ROA of a control firm, matched on primary two-digit SIC industry and with the ROA within $10 \%$ in the previous year. If no firm in the same two-digit industry has a year-1 ROA within $10 \%$, I first select the firm in the same one- digit industry, and then disregard industry and only match on year-1 ROA within $10 \%$. Definitions of all variables are in the Appendix. ***,**, and * indicate statistical significance at the $1 \%, 5 \%$, and $10 \%$ level, respectively. $p$-values are reported in the parentheses.

Table 6. Multivariate analysis: Change in firm performance around incumbent CEOs' actual departure in firms

\begin{tabular}{|c|c|c|c|}
\hline Independent variables & $\begin{array}{l}\text { (1) Change in Indperf } \\
\text { ROA }_{t+1}\end{array}$ & $\begin{array}{l}\text { (1) Change in } \\
\text { Indperf }_{\mathrm{t}+2}\end{array}$ & $\begin{array}{l}\text { (2) Change } \\
\text { Indperf }{ }_{t+3}\end{array}$ \\
\hline \multirow[t]{2}{*}{ Below median lead time } & $-1.162 * * *$ & $-1.060 *$ & -0.197 \\
\hline & $(0.00)$ & $(0.09)$ & $(0.82)$ \\
\hline \multirow[t]{2}{*}{ Log (Market cap) } & 0.163 & 0.242 & 0.312 \\
\hline & $(0.54)$ & $(0.37)$ & $(0.29)$ \\
\hline \multirow[t]{2}{*}{ Founder CEO } & 0.572 & -0.044 & -0.438 \\
\hline & $(0.70)$ & $(0.98)$ & $(0.78)$ \\
\hline \multirow[t]{2}{*}{ Firm risk $(\%)$} & -0.266 & 0.322 & -0.438 \\
\hline & $(0.65)$ & $(0.61)$ & $(0.50)$ \\
\hline \multirow[t]{2}{*}{ Indperf_ROA ${ }_{t-l}(\%)$} & $-0.557 *$ & $-1.064 * *$ & $-1.397 * * *$ \\
\hline & $(0.09)$ & $(0.02)$ & $(0.00)$ \\
\hline R\&D intensity (\%) & 0.187 & 0.047 & 0.286 \\
\hline
\end{tabular}




\begin{tabular}{llll} 
& $(0.21)$ & $(0.80)$ & $(0.11)$ \\
Free Cash Flow (\%) & -0.041 & -0.052 & -0.080 \\
& $(0.62)$ & $(0.59)$ & $(0.45)$ \\
Institutional ownership (\%) & 0.014 & 0.003 & 0.002 \\
Leverage $(\%)$ & $(0.28)$ & $(0.83)$ & $(0.88)$ \\
& 0.007 & 0.030 & 0.005 \\
Constant, year and industry & $(0.74)$ & $(0.24)$ & $(0.88)$ \\
dummies & & & Yes \\
Number of observations & 873 & Yes & 806 \\
R-sq & 0.055 & 839 & 0.059 \\
\hline
\end{tabular}

I next examine the relationship between lead time and changes in firm operating performance. Table 6 shows the results of the coefficients using OLS regression with the White robustness errors. The dependent variables are changes in industry-and-performance-adjusted ROA from one year before to three years after the departure. Multivariate regressions show that controlling for prior year industry-and-performance-adjusted ROA, there is a negative relation between below-median lead time and change in operating performance. A change from above to below-median lead time is associated with decreases in ROAs of $1.16 \%$ and $1.06 \%$ from one year before to two years after the departure. The results on change in firm operating performance are consistent with my prediction that firms with short lead time not only have lower stock performance around the announcement, they may also have lower firm operating performance. Therefore, a lack of time to plan for CEO succession may create disruption cost in the longer term.

\subsection{Propensity Score Matching}

It is possible that the correlation between lead time and disruption cost I have identified is caused by other factors such as the firm size and FCF differences, and is not related to whether firms have a succession plan. In order to address the endogeneity issue, I provide additional tests using propensity score matching estimation, matching firms with unexpected CEO departures (treatment group) to firms with planned retirement (control group). The key identifying assumption of this methodology is that, in absence of treatment, the observed change in outcome would be identical across the treatment group and control group (Gilje and Taillard 2014). In the context of this paper, the treatment (i.e. difference by design) is whether the CEO departure is unexpected. Based on the findings in Table 2, firms with planned retirement and those with unexpected CEO departures seem to be fairly homogeneous in nature. In particular, the control group and treatment group are similar in many dimensions, including firm age, firm value, prior firm performance, and board characteristics. There is no statistically and economically significant difference in firm and board characteristics, apart from firm size (measured by market capitalization) and free cash flows (FCF). Therefore, I test whether the observed differences in disruption costs are caused by these factors and are not correlated with the time and likelihood of CEO succession planning (i.e. lead time). For each firm in the treatment group, I match control groups based on factors including industry, firm size (both sales and market capitalization), FCF and prior firm performance. I use one-to-one nearest neighbor match with no replacement, the closest three matches, as well as the closest five matches to ensure that results are not driven by matching techniques. Davis and Song (2009) argue that the one-to-one nearest neighbor match provides the greatest comparative power and the less size distortion. However, I find that the nearest three matches provide the best results in my paper, because of the small sample issue associated with one-to-one nearest neighborhood match with no replacement $(\mathrm{N}=71)$.

Table 7 shows the estimate of OLS regressions of excess stock returns around the first public announcement of CEO departure, using propensity score matching estimation, matching with the closest three neighbors with replacement. The treatment group is firms with unexpected CEO departures, and the control group is firms with planned retirement. The dependent variables are value-weighted-market-adjusted excess stock returns. For each firm in the treatment group, I match control groups based on factors including industry (four digit SIC code), firm size (both sales and market capitalization), free cash flow (FCF) and prior firm performance. I use one-to-one nearest neighborhood match with no replacement (not tabulated), the closest three matches, as well as the closest five matches (not tabulated) to ensure that results are not driven by matching techniques. Out of the 76 firms with 
unexpected CEO departure, 5 have no matching firms in the control group. All dependent variables are in the percentage format. $* * *, * *$, and $*$ indicate statistical significance at the $1 \%, 5 \%$, and $10 \%$ level, respectively. $p$-values are reported in the parentheses.

Table 7. Propensity score matched firms: excess stock returns after incumbent CEO departure

\begin{tabular}{|c|c|c|c|c|c|c|}
\hline Independent variables & $\begin{array}{l}\text { (1) CARs } \\
(0,0)(\%)\end{array}$ & $\begin{array}{l}\text { (2) CARs } \\
(0,0)(\%)\end{array}$ & $\begin{array}{l}(3) \text { CARs } \\
(-1,1) \quad(\%)\end{array}$ & $\begin{array}{ll}(4) & \text { CARs } \\
(-1,1) & (\%)\end{array}$ & $\begin{array}{l}(5) \quad \text { CARs } \\
(-3,3)(\%)\end{array}$ & $\begin{array}{l}(6) \quad \text { CARs } \\
(-3,3)(\%)\end{array}$ \\
\hline \multirow[t]{2}{*}{ Unexpected departure } & $-1.530 * * *$ & -0.437 & $-2.410 * * *$ & -1.030 & $-2.810 * * *$ & $-1.960 *$ \\
\hline & $(0.01)$ & $(0.65)$ & $(0.00)$ & $(0.39)$ & $(0.00)$ & $(0.10)$ \\
\hline \multirow{2}{*}{$\begin{array}{l}\text { Non heir apparent } \\
\text { succession }\end{array}$} & -0.026 & 0.098 & -0.137 & 0.017 & -0.015 & 0.056 \\
\hline & $(0.90)$ & $(0.65)$ & $(0.69)$ & $(0.96)$ & $(0.88)$ & $(0.92)$ \\
\hline Unexpected departure & & $-1.187 *$ & & $-2.381 *$ & & -1.460 \\
\hline $\begin{array}{l}\text { * Non heir apparent } \\
\text { succession }\end{array}$ & & $(0.09)$ & & $(0.08)$ & & $(0.36)$ \\
\hline \multirow[t]{2}{*}{ Log (Market cap) } & 0.014 & 0.032 & 0.056 & 0.089 & 0.092 & 0.114 \\
\hline & $(0.85)$ & $(0.68)$ & $(0.71)$ & $(0.57)$ & $(0.67)$ & $(0.62)$ \\
\hline \multirow[t]{2}{*}{ Founder CEO } & -0.262 & -0.206 & -0.311 & -0.166 & 1.380 & 1.530 \\
\hline & $(0.50)$ & $(0.62)$ & $(0.62)$ & $(0.80)$ & $(0.15)$ & $(0.13)$ \\
\hline \multirow[t]{2}{*}{ Firm risk (\%) } & 0.069 & 0.083 & 0.169 & 0.216 & 0.198 & 0.267 \\
\hline & $(0.70)$ & $(0.65)$ & $(0.59)$ & $(0.51)$ & $(0.64)$ & $(0.55)$ \\
\hline \multirow[t]{2}{*}{ R\&D intensity (\%) } & -0.014 & -0.001 & 0.124 & $0.157^{*}$ & -0.093 & -0.095 \\
\hline & $(0.73)$ & $(0.98)$ & $(0.14)$ & $(0.06)$ & $(0.72)$ & $(0.86)$ \\
\hline \multirow[t]{2}{*}{$\begin{array}{l}\text { Institutional } \\
\text { ownership (\%) }\end{array}$} & $-0.016^{* *}$ & $-0.010 * *$ & $-0.013 * *$ & $-0.013 * *$ & $-0.018^{*}$ & $-0.018^{*}$ \\
\hline & $(0.02)$ & $(0.03)$ & $(0.05)$ & $(0.04)$ & $(0.06)$ & $(0.08)$ \\
\hline \multirow[t]{2}{*}{$\begin{array}{l}\text { Prior } 1 \mathrm{yr} \text { stock return } \\
(\%)\end{array}$} & 0.003 & 0.004 & 0.007 & 0.008 & -0.008 & -0.009 \\
\hline & $(0.33)$ & $(0.23)$ & $(0.17)$ & $(0.12)$ & $(0.32)$ & $(0.30)$ \\
\hline \multirow[t]{2}{*}{ Leverage $(\%)$} & 0.001 & 0.002 & -0.002 & -0.002 & 0.003 & 0.005 \\
\hline & $(0.89)$ & $(0.85)$ & $(0.86)$ & $(0.85)$ & $(0.88)$ & $(0.75)$ \\
\hline \multirow[t]{2}{*}{ Free cash flow (\%) } & -0.001 & -0.013 & -0.067 & -0.077 & -0.042 & -0.443 \\
\hline & $(0.96)$ & $(0.56)$ & $(0.15)$ & $(0.11)$ & $(0.46)$ & $(0.46)$ \\
\hline $\begin{array}{l}\text { Constant, year and } \\
\text { industry dummies }\end{array}$ & Yes & Yes & Yes & Yes & Yes & Yes \\
\hline $\begin{array}{ll}\text { Number } & \text { of } \\
\text { observations } & \end{array}$ & 865 & 865 & 865 & 865 & 865 & 865 \\
\hline R-sq & 0.045 & 0.051 & 0.057 & 0.060 & 0.040 & 0.041 \\
\hline
\end{tabular}

Tables 7 and 8 present the results of the matching sample estimation. Out of the 76 firms with unexpected CEO departures, 5 have no matches in the control sample. Table 7 shows that after controlling for potential differences in firm size, prior performance and managerial discretions, firms with unexpected CEO departures are associated with 
more negative abnormal returns at the first public announcement of CEO departure. In regressions (1), (3), and (5), the CARs are $-1.53 \%,-2.41 \%$, and $-2.81 \%$ in the event windows $(0,0),(-1,1)$, and $(-3,3)$, respectively $(\mathrm{p}<=0.01)$. In addition, firms may make suboptimal choices in selecting the new CEO when they are faced with an unexpected CEO departure. Specifically, in regressions (2), (4), and (6), the key coefficients on the interaction term between unexpected departure and non heir apparent succession are significantly negative at -1.187 and $-2.381(\mathrm{p}<=0.10)$ for the two event windows $(0,0)$ and $(-1,1)$. This result indicates instead of carefully selecting and grooming an heir apparent, firms may rush into appointing a new CEO through horse race or outside succession. In addition, incumbent CEOs are not able to be involved in the selection process when they depart unexpectedly. These two factors may lead firms to make suboptimal choices in selecting the new CEO.

Table 8 shows the estimate of OLS regressions of change in firm performance, measured by change in sales and change in industry-and-performance-adjusted ROAs from one year before departure to three years after the actual departure. These results are based on propensity score matching estimation, matching each firm in the treatment group to the nearest three neighbors in the control group, based on factors including industry (four digit SIC code), firm size (both sales and market capitalization), free cash flow (FCF) and prior firm performance. The dependent variables are changes in industry-and-performance-adjusted ROAs in regressions (1)-(3), and changes in sales scaled by sales the year prior to the CEO departure in regressions (4)-(6). Definitions of all variables are in the Appendix. ***,**, and * indicate statistical significance at the $1 \%, 5 \%$, and $10 \%$ level, respectively. p-values are reported in the parentheses.

Table 8. Propensity score matched firms: Change in firm performance around incumbent CEOs' actual departure

\begin{tabular}{|c|c|c|c|c|c|c|}
\hline Independent variables & $\begin{array}{l}\text { (1) } \\
\text { Change in } \\
\text { indperf_ROA } \text { ROt }_{4} \\
(\%)\end{array}$ & $\begin{array}{l}\text { Change in } \\
\text { indperf } \mathrm{ROA}_{\mathrm{t}+2} \\
(\%)\end{array}$ & $\begin{array}{l}\text { Change in } \\
\text { indperf } \mathrm{ROA}_{4+3} \\
(\%)\end{array}$ & $\begin{array}{l}\text { (4) } \\
\text { Change in } \\
\text { sales } \\
(\%)\end{array}$ & $\begin{array}{l}\text { (5) } \\
\text { Change in } \\
\text { sales }+2 \\
(\%)\end{array}$ & $\begin{array}{l}\text { (6) } \\
\text { Change in } \\
\text { salest }{ }^{+}+3 \\
(\%)\end{array}$ \\
\hline \multirow[t]{2}{*}{ Below median lead time } & $-1.690^{* * *}$ & $-1.230^{*}$ & -0.645 & $-5.270^{* *}$ & $-4.330^{*}$ & $-6.570^{*}$ \\
\hline & $(0.01)$ & $(0.09)$ & $(0.45)$ & $(0.02)$ & $(0.10)$ & $(0.09)$ \\
\hline Indperf_ROA & $\begin{array}{l}-0.484 \\
(0.26)\end{array}$ & $\begin{array}{l}-1.042^{* *} \\
(0.02)\end{array}$ & $\begin{array}{l}-1.329 * * * \\
(0.01)\end{array}$ & & & \\
\hline Sale $_{t, l}$ & & & & $\begin{array}{l}-0.000 \\
(0.40)\end{array}$ & $\begin{array}{l}-0.000 \\
(0.20)\end{array}$ & $\begin{array}{l}-0.000^{*} \\
(0.09)\end{array}$ \\
\hline Prior 1 yr stock return (\%) & & & & $\begin{array}{l}0.120^{* * *} \\
(0.00)\end{array}$ & $\begin{array}{l}0.150^{* * *} \\
(0.00)\end{array}$ & $\begin{array}{l}-0.220^{* * *} \\
(0.00)\end{array}$ \\
\hline Log (Market cap) & $\begin{array}{l}0.234 \\
(0.41)\end{array}$ & $\begin{array}{l}0.482^{*} \\
(0.10)\end{array}$ & $\begin{array}{l}0.325 \\
(0.32)\end{array}$ & $\begin{array}{l}1.112 \\
(0.33)\end{array}$ & $\begin{array}{l}2.440^{*} \\
(0.10)\end{array}$ & $\begin{array}{l}2.950 \\
(0.12)\end{array}$ \\
\hline Founder CEO & $\begin{array}{l}0.717 \\
(0.62)\end{array}$ & $\begin{array}{l}0.054 \\
(0.97)\end{array}$ & $\begin{array}{l}-0.186 \\
(0.91)\end{array}$ & $\begin{array}{l}3.040 \\
(0.50)\end{array}$ & $\begin{array}{l}4.200 \\
(0.42)\end{array}$ & $\begin{array}{l}4.420 \\
(0.54)\end{array}$ \\
\hline Firm risk (\%) & $\begin{array}{l}-0.351 \\
(0.52)\end{array}$ & $\begin{array}{l}-0.086 \\
(0.89)\end{array}$ & $\begin{array}{l}-0.116 \\
(0.87)\end{array}$ & $\begin{array}{l}1.450 \\
(0.45)\end{array}$ & $\begin{array}{l}0.752 \\
(0.77)\end{array}$ & $\begin{array}{l}0.441 \\
(0.89)\end{array}$ \\
\hline R\&D intensity (\%) & $\begin{array}{l}0.161 \\
(0.26)\end{array}$ & $\begin{array}{l}0.230 \\
(0.16)\end{array}$ & $\begin{array}{l}0.157 \\
(0.34)\end{array}$ & $\begin{array}{l}-0.116 \\
(0.74)\end{array}$ & $\begin{array}{l}0.011 \\
(0.98)\end{array}$ & $\begin{array}{l}-0.112 \\
(0.87)\end{array}$ \\
\hline Independent variables & $\begin{array}{l}(1) \\
\text { Change in } \\
\text { indperf_ROA } \\
\text { (\%) }\end{array}$ & $\begin{array}{l}\text { (2) } \\
\text { Change in } \\
\text { indperf_ROA } \\
\text { (\%) }\end{array}$ & $\begin{array}{l}\text { (3) } \\
\text { Change in } \\
\text { indperf_ROA } A_{+3} \\
\text { (\%) }\end{array}$ & $\begin{array}{l}\text { (4) } \\
\text { Change in } \\
\text { sales }+1 \\
(\%)\end{array}$ & $\begin{array}{l}\text { (5) } \\
\text { Change in } \\
\text { salest } 2 \text {. } \\
(\%)\end{array}$ & $\begin{array}{l}\text { (6) } \\
\text { Change in } \\
\text { salest }+3 \\
(\%)\end{array}$ \\
\hline \multirow[t]{2}{*}{ Free Cash Flow (\%) } & -0.025 & -0.020 & -0.764 & -0.041 & -0.053 & -0.069 \\
\hline & $(0.77)$ & $(0.81)$ & $(0.94)$ & $(0.86)$ & $(0.85)$ & $(0.84)$ \\
\hline Institutional ownership (\%) & $\begin{array}{l}0.007 \\
(0.62)\end{array}$ & $\begin{array}{l}0.005 \\
0.72)\end{array}$ & $\begin{array}{l}0.012 \\
(0.45)\end{array}$ & $\begin{array}{l}0.046 \\
(0.34)\end{array}$ & $\begin{array}{l}0.036 \\
0.577\end{array}$ & $\begin{array}{l}0.083 \\
0.30\end{array}$ \\
\hline Leverage (\%) & $\begin{array}{l}0.019 \\
(0.38)\end{array}$ & $\begin{array}{l}0.019 \\
(0.42)\end{array}$ & $\begin{array}{l}-0.004 \\
(0.89)\end{array}$ & $\begin{array}{l}-0.109 \\
(0.14)\end{array}$ & $\begin{array}{l}-0.114 \\
(0.25)\end{array}$ & $\begin{array}{l}-0.174 \\
(0.15)\end{array}$ \\
\hline $\begin{array}{l}\text { Constant, year and industry } \\
\text { dummies } \\
\text { Number of observations }\end{array}$ & $\begin{array}{l}\text { Yes } \\
833\end{array}$ & $\begin{array}{l}\text { Yes } \\
799\end{array}$ & $\begin{array}{l}\text { Yes } \\
723\end{array}$ & $\begin{array}{l}\text { Yes } \\
842\end{array}$ & $\begin{array}{l}\text { Yes } \\
816\end{array}$ & $\begin{array}{l}\text { Yes } \\
777\end{array}$ \\
\hline R-sq & 0.052 & 0.048 & 0.048 & 0.087 & 0.085 & 0.106 \\
\hline
\end{tabular}

In addition to evaluate the relationship between lack of lead time in succession and stock performance, I also test the whether having no plan could negatively impact firm operating performance in the long run. Table 8 shows the regression results using the propensity score matching samples. The dependent variables are change in industry-and-performance-adjusted ROAs and change in sales, scaled by sales the year before CEO departure. The results are consistent with Table 5 and 6 . Firms with below-median lead time have significantly lower change in sales and change in ROA for up to two years after the CEO departure ( $\mathrm{p}<=0.10)$.

Overall, these results demonstrate that the average outcome observed in earlier analysis are not simply driven by other factors, such as firm size, FCF, and prior firm performance. Lead time is significantly correlated with different 
measures of disruption costs. The results using one-to-one nearest neighbor match as well as the nearest five neighbor match provide similar results, therefore are not tabulated in the paper.

\section{Comparison of Board Adjustments}

Table 9 shows the board and director characteristics three years prior to the CEO departure. Bolded letters $c, b$, and $a$ indicate a two-sided t-test for mean differences between firms with planned and unexpected CEO departures are significant at $1 \%, 5 \%$ and $10 \%$ level. Panel A shows the change firms make to the board every year from three years before the CEO turnover. Panel B tabulates the percentage of firms appointed COO and/president as well as the percentage of firms appointed their CEO candidate to the board each year. Definitions of all variables are in the Appendix.

Table 9. Firm and board adjustment comparison

Panel A

\begin{tabular}{lllllll}
\hline & \multicolumn{3}{l}{ Planned retirement $(\mathrm{N}=843)$} & \multicolumn{3}{c}{$\begin{array}{l}\text { Unexpected departures } \\
(\mathrm{N}=76)\end{array}$} \\
\hline & $\mathrm{t}-3$ & $\Delta \mathrm{t}-2$ & $\Delta \mathrm{t}-1$ & $\mathrm{t}-3$ & $\Delta \mathrm{t}-2$ & $\Delta \mathrm{t}-1$ \\
\cline { 2 - 7 } Board size & 9.94 & 0.03 & 0.01 & 10.02 & -0.13 & 0.06 \\
Board independence & $65.71 \%$ & $\mathbf{0 . 9 8 \%}$ & $1.17 \%$ & $63.33 \%$ & $\mathbf{3 . 5 2 \%}$ & $1.89 \%$ \\
Existing director turnover & $\mathbf{9 . 2 5 \%}$ & $-0.58 \%$ & $2.01 \%$ & $\mathbf{1 2 . 0 4 \%}$ & $-0.20 \%$ & $2.49 \%$ \\
Free cash flow & $4.28 \%$ & $-0.25 \%$ & $\mathbf{0 . 0 7 \%}$ & $3.97 \%$ & $-0.25 \%$ & $\mathbf{- 1 . 4 5 \%}$ \\
Capital expenditure $(000,000)$ & 331.67 & $18.91 \%$ & $17.39 \%$ & 216.27 & $31.41 \%$ & $24.09 \%$ \\
\hline
\end{tabular}

Panel B

\begin{tabular}{lllllll}
\hline & $\mathrm{t}-3$ & $\mathrm{t}-2$ & $\mathrm{t}-1$ & $\mathrm{t}-3$ & $\mathrm{t}-2$ & $\mathrm{t}-1$ \\
\cline { 2 - 7 } $\begin{array}{l}\text { \% of firms apt COO/Pres } \\
\begin{array}{l}\text { \% of firms apt new CEO on } \\
\text { board }\end{array}\end{array}$ & \begin{tabular}{l}
$\mathbf{1 3 . 0 5 \%}$ \\
\hline
\end{tabular} & $\mathbf{1 2 . 8 1 \%}$ & $5.26 \%$ & $\mathbf{3 . 9 4 \%}^{\mathrm{a}}$ & $\mathbf{2 . 6 3 \%}^{\mathrm{a}}$ \\
\hline
\end{tabular}

Based on my earlier assumption that when firms have longer lead time, they may be able to compose a succession plan even when there is none in place. In this section, I examine board adjustments firms make in order to prepare for succession planning. Table 9 shows the comparison of board characteristics over a three-year period prior to CEO departure in firms with planned retirement and unexpected departures. Both types of firms have similar board size and independence, as well as the change in board size and independence. From two years to one year before the power transition, both subsamples experience an increase in existing director turnover, possibly caused by the shift in board composition, when firms start putting the successor on board. Specifically, 17.32\% of the CEO successor joined the board at least one year before the planned departure, compared to $2.56 \%$ before the unexpected CEO departures. This result demonstrates that when firms have a succession plan in place or in progress, appointing the new CEO to the board at least one to two years in advance may be part of the actions firms make to the board in anticipation of the transition of power.

\section{Conclusion}

While CEO succession planning has received a lot of attention - particularly in social media, there has been a dearth of studies evaluating its necessity. Moreover, the succession planning process itself has not been clearly described, possibly because this process is difficult to observe and evaluate. In this paper, I determine whether and how lead time in CEO succession matters and examine which actions firms and board of directors take to prepare for a succession in the company's top executive leadership. To do so, I use a novel measure - lead time to proxy for the time firms have to plan for succession, if there is none already in place. I compare firms with planned departures (i.e. retirements) to firms with unexpected CEO departures and find that firms with planned CEO departures have significantly longer lead time and lower disruption costs. Specifically, when the CEO departure is planned, firms 
tend to experience significantly less negative excess stock returns and more favorable change in firm performance. In fact, it can save firms $\$ 136$ million if the CEO retires rather than unexpectedly dies or becomes ill. Given the large magnitude of the change in firm value associated with the possibility of succession planning, I argue that it is doubtful that the costs of not planning for succession will outweigh the benefits. This paper contributes to the CEO succession planning literature by showing that longer lead time in CEO succession planning is critical to lower disruption costs and ensure a smoother transition. Thus, the new SEC requirement that CEO succession planning be fully elevated to the status of core board responsibility is empirically supported.

\section{Acknowledgement}

I thank Tina Yang, Tracie Woidtke, Mike Ehrhardt, Ramon DeGenaaro, and Bruce Behn, as well as Michael Goldstein, Laurie Krigman, and other participants at the outside speaker seminar at the University of Tennessee and Babson College for their helpful comments and suggestions.

\section{References}

Adams, R. B., \& Ferreira, D. (2007). A theory of friendly boards. The Journal of Finance, 62, 217-250. https://doi.org/10.1111/j.1540-6261.2007.01206.x

Adams, R. B., Almeida, H., \& Ferreira, D. (2005). Powerful CEO and their impact on corporate policies. Review of Financial Studies, 18(4), 1403-1432. https://doi.org/10.1093/rfs/hhi030

Agrawal, A., Knoeber, C., \& Tsoulouhas, T. (2006). Are Outsiders Handicapped in CEO Successions?. Journal of Corporate Finance. https://doi.org/10.1016/j.jcorpfin.2004.04.005

Barber, B. M., \& Lyon, J. D. (1996). Detecting abnormal performance. The empirical power and specification of test statistics. Journal of Financial Economics, 41, 359-399. https://doi.org/10.1016/0304-405X(96)84701-5

Behn, B. K., Dawley, D. D., Riley, R., \& Yang, Y.-W. (2005). The value of an heir apparent in succession planning. Corporate Governance, 13, 168-177. https://doi.org/10.1111/j.1467-8683.2005.00415.x

Behn, B. K., Riley, R. A. Jr., \& Yang, Y.-W. (2006). Deaths of CEOs: are delays in naming successors and insider/outsider succession associated with subsequent firm performance?. Journal of Managerial Issues, 18, $32-46$.

Booth, J. R., \& Deli, D. N. (1996). Factors affecting the number of outside directorships held by CEOs. Journal of Financial Economics, 40, 81-104. https://doi.org/10.1016/0304-405X(95)00838-6

Booth, J. R., \& Deli, D. N. (1999). On executives of financial institutions as outside directors. Journal of Corporate Finance, 5, 227-250. https://doi.org/10.1016/S0929-1199(99)00004-8

Borokhovich, K., R., \& Parrino, T. T. (1996). Outside Directors and CEO Selection. Journal of Financial and Quantitative Analysis, 31, 337-355. https://doi.org/10.2307/2331395

Brickley, J. (2003). Empirical research on CEO turnover and firm-performance: a discussion. Journal of Accounting and Economics, 36, 227-233. https://doi.org/10.1016/j.jacceco.2003.09.003

Brickley, J., Coles, J., \& Jarrell, G. (1997). Leadership Structure: Separating the CEO and Chairman of the Board. Journal of Corporate Finance, 3, 189-220. https://doi.org/10.1016/S0929-1199(96)00013-2

Brickley, J., Linck, J., S., \& Coles, J. L. (1998). What happens to CEOs after they retire? New evidence on career concerns, horizon problems, and CEO incentives. Journal of Financial Economics, 52, 341-77. https://doi.org/10.1016/S0304-405X(99)00012-4

Cannella, A., Jr., \& Lubatkin, M. (1993). Succession as a sociopolitical process: Internal impediments to outsider selection. Academy of Management Journal, 36, 763-793. https://doi.org/10.2307/256758

Coles, J. L., Daniel, N. D., \& Naveen, L. (2008). Boards: does one size fit all?. Journal of Financial Economics, 82, 329-356. https://doi.org/10.1016/j.jfineco.2006.08.008

Davis, R., \& Kim, S. S. (2008). Using matched samples to test for differences in trade execution costs. Journal of Financial Markets, 12, 173-202. https://doi.org/10.1016/j.finmar.2008.06.001

Davis, S., \& Nosal, D. (2009). Smart planning for CEO succession. The Corporate Board, 30(178), 17.

Denis, D., \& Denis, D. (1995). Performance changes following top management_dismissals. Journal of Finance, 50, 1029-1057. https://doi.org/10.1111/j.1540-6261.1995.tb04049.x 
Fama, E. F. (1980). Agency problem and the theory of the firm. Journal of Political Economy, 88, 288-307. https://doi.org/10.1086/260866

Fama, E. F., \& Jensen, M. C. (1983). Separation of ownership and control. Journal of Law and Economics, 26, 301-325. https://doi.org/10.1086/467037

Gilje, E., \& Tailard, J. P. (2014). Does risk management affect firm value? Evidence from a natural experiment. Working paper.

Harris, M., \& Raviv, A. (2008). A theory of board control and size. Review of Financial Studies, 21(4), 1797-183. https://doi.org/10.1093/rfs/hhl030

Hermalin, B. E., \& Weisbach, M. S. (2003). Endogenously chosen boards of directors and their monitoring of the CEO. American Economic Review, 88, 96-118.

Huson, M., Malatesta, P., \& Parrino, R. (2004). Managerial succession and firm performance. Journal of Financial Economics, 74, 237-275. https://doi.org/10.1016/j.jfineco.2003.08.002

Hwang, B., \& Kim, S. (2009, July). It pays to have friends. Journal of Financial Economics, 93, 138-158. https://doi.org/10.1016/j.jfineco.2008.07.005

Jensen, M. C., \& Meckling, W. H. (1976). Theory of the Firm: Managerial Behavior, Agency Costs and Ownership Structure. Journal of Financial Economics, 3, 305-360. https://doi.org/10.1016/0304-405X(76)90026-X

Jenter, D., Matveyev, E., \& Roth, L. (2016). Good and bad CEOs. Working paper.

Larcker, D. F., \& Saslow, S. (2014). Reports on senior executive succession planning and talent development. Stanford University and IED.

Linck, J. S., Netter, J. M., \& Yang, T. (2009). The Effects and Unintended Consequences of the Sarbanes-Oxley Act on the Supply and Demand for Directors. Review of Financial Studies, 22, 3297-3323. https://doi.org/10.1093/rfs/hhn084

Masulis, R., \& Shawn, M. (2009). Are all inside directors the same? Evidence from external directorship market. The Journal of Finance, 66, 823-872. https://doi.org/10.1111/j.1540-6261.2011.01653.x

McConnell, J., \& Qi, Q. (2016). Just talk? CEO succession plan disclosure, corporate governance and firm value. Working paper. https://doi.org/10.2139/ssrn.2871628

Parrino, R. (1997). CEO Turnover and Outside Succession: A Cross-Sectional Analysis. Journal of Financial Economics, 46, 165-197. https://doi.org/10.1016/S0304-405X(97)00028-7

Salas, J. M. (2010). Entrenchment, governance and the stock price reaction to sudden executive deaths. Journal of Business and Finance, 34, 656-666. https://doi.org/10.1016/j.jbankfin.2009.09.002

Shen, W., \& Cannella, A. A. Jr. (2002). Revisiting the performance consequences of CEO succession: the impacts of successor type, post succession senior executive turnover, and departing CEO tenure. The Academy of Management Journal, 45(4), 717-733. https://doi.org/10.2307/3069306

Shivdasani, A., \& Yermack, D. (1999). CEO Involvement in the Selection of New Board Members: An Empirical Analysis. Journal of Finance, 54, 1829-1853. https://doi.org/10.1111/0022-1082.00168

Weisbach, M. (1988). Outside directors and CEO turnover. Journal of Financial Economics, 20, 431-60. https://doi.org/10.1016/0304-405X(88)90053-0

Worrell, D. L., Davidson III, W. N., Chandy, P. R., \& Garrison, S. L. (1986). Management turnover through deaths of key executives: effects on investor wealth. Academy of Management, 29, 674-694. https://doi.org/10.2307/255939

Zhang, Y., \& Rajagopalan, N. (2004). When the known devil is better than an unknown god: an empirical study of the antecedents and consequences of relay CEO successions. Academy of Management, 47(4), 483-500. https://doi.org/10.2307/20159598

Zhang, Y., \& Rajagopalan, N. (2010). CEO succession planning: Finally at the center stage of the boardroom. Business Horizons, 53, 455-462. https://doi.org/10.1016/j.bushor.2010.05.003

\section{Notes}

Note 1. Consider for instance the recent change in leadership at Ford Motor Co. When announcing that Mark Field will succeed Allan Mulally as new Chief Executive Officer, Ford's spokeswoman mentioned that the "company 
takes succession planning very seriously and has succession plans in place for each of the key leadership positions. However, for competitive reasons, Ford does not discuss succession plans externally". Keith Naughton, April 21, 2014, Ford said to decide on Fields as CEO as Mulally plans departure (Bloomberg).

Note 2. Key words indicating an orderly transition of power include, but are not limited to: "succession", "succession planning", "succession plan", "natural transition", "retirement age", "retirement", and "orderly transition of power".

Note 3. Hendrick and Struggle 2010 survey on CEO succession planning of 140 CEOs and directors of North America public and private companies. Source: http://rockcenter.law.stanford.edu/wp-content/uploads/2010/06/CEO-Survey-Brochure-Final2.pdf

Note 4. This database is now called Risk Metrics.

Note 5. Financial and utility firms are excluded from my sample.

Note 6. Keith Naughton, April 21, 2014, Ford said to decide on Fields as CEO as Mulally plans departure (Bloomberg).

Note 7. David Larker and Scott Saslow, 2014 Reports on senior executive succession planning and talent development, The Conference Board, IED, Stanford University, 2014. The survey results are based on interviews with board members and senior executives in 20 companies between June and December 2013.

Note 8. Jeffrey Green and Hideki Suzuki, Board of director pay hits record $\$ 251,000$ for 250 hours, BloombergBusiness, May 30, 2014.

Note 9. David Larker and Scott Saslow, 2014 Reports on senior executive succession planning and talent development, The Conference Board, IED, Stanford University, 2014. The survey results are based on interviews with board members and senior executives in 20 companies between June and December 2013.

Note 10. Jeffrey Green and Hideki Suzuki, Board of director pay hits record $\$ 251,000$ for 250 hours, BloombergBusiness, May 30, 2014.

\section{Appendix A1}

$\underline{\text { Variable definitions }}$

Below median lead time is a binary variable that equals to 1 if firms have below median lead time, and 0 if firms have above median lead time.

Blockholder is a binary variable that equals to 1 if there is at least one blockholder in the sample firm, and 0 otherwise. Blockholder and institutional ownership information are obtained from Thomson Financial database.

Change in Indperfadj ROA is the change in industry-and-performance-adjusted ROAs from one year up to three years after the incumbent CEO departure.

Lead time is the number of days between the incumbent CEOs' departure announcement date and their actual departure date.

Days before new CEO takeover is the number of days between the incumbent CEOs' departure announcement date and actual date the new CEO takes over.

Days without leadership is the number of days firms operate without CEO leadership.

Days since new CEO appt COO/President is the executive tenure as $\mathrm{COO}$ and/or President.

Departing CEO founder is a binary variable that equals to 1 if the departing CEO was the founder, and 0 otherwise.

Firm age is the maximum number of years between CRSP listing age and Compustat listing age.

Firm risk $\boldsymbol{t}_{t-1}$ is the standard deviation of daily stock price during the prior calendar year.

Industry-adjusted $\mathbf{R O A}_{t-1}$ is measured as a sample firm's ROA minus the median industry ROA, using the Fama and French (1997) 48-industry classification.

Industry-and-performance-adjusted $\mathbf{R O A}_{t-1}$ is defined as each sample firm's ROA less the ROA of a non sample firm, matched on primary two-digit SIC industry and with the ROA within 10\% in the previous year. If no firm in the same two-digit industry has a year-1 ROA within $10 \%$, I first select the firm in the same one- digit industry, and then disregard industry and only match on year-1 ROA within $10 \%$.

Market value of equity (mkcap) is calculated using end of the year closing price of equity to multiply common stock shares outstanding. 
New CEO is current employee is a binary variable that equals to 1 if the replacement CEO has been with the hiring company for at least 2 years prior to the departure, and 0 if the they are hired from outside (this is a result not summary stats).

New CEO is Current director is an indicator variable that equals to 1 if the replacement CEO has been a director in the firm for at least 6 months, and 0 otherwise.

New CEO Age is obtained from Execucomp as of the year of CEO departure.

New CEO \# of external board seats is the total number of other public board connections the new CEO possesses.

Non heir apparent succession is a binary variable that equals to 1 if firms implemented horse race succession (allowing internal candidates to compete for the new CEO position) or outside successions, and 0 otherwise.

Outside director connections is calculated as the sum of other public board seats held by outside directors in the sample firm.

Post year 2001 is a binary variable that equals to 1 if the year of departure is after 2001, 0 otherwise.

Percentage of insider directors and Number of inside directors are the percentage and number of inside directors on board.

Relay succession is an indicator variable that equals to 1 if the new CEO has been the $\mathrm{COO}$ and/or President before they were promoted.

$\boldsymbol{R} \& \boldsymbol{D}$ intensity is defined as research and development expenditure to sales. I calculate R\&D intensity by taking the maximum value of 0 , or $R \& D$ expense from Compustat, whichever is larger, and then divide it by sales.

$\boldsymbol{R O A}$ is the operating earnings before interest and taxes (OIBDP) over total book assets (AT).

Total \# of inside directors is the total number of inside directors on board.

\% of existing director departures $t_{t+n}$ is the percentage of existing director turnover rate up to three years after the CEO departure.

\% of senior management turnover within 18mons is the percentage of senior management (president, $\mathrm{CFO}$, and COO) that left the company 18 months after the departures. 